This item was submitted to Loughborough's Research Repository by the author.

Items in Figshare are protected by copyright, with all rights reserved, unless otherwise indicated.

\title{
The populist cat-dog: applying the concept of populism to contemporary European party systems
}

PLEASE CITE THE PUBLISHED VERSION

http://dx.doi.org/10.1080/13569317.2013.869457

PUBLISHER

(c) Taylor \& Francis

VERSION

AM (Accepted Manuscript)

\section{PUBLISHER STATEMENT}

This work is made available according to the conditions of the Creative Commons Attribution-NonCommercialNoDerivatives 4.0 International (CC BY-NC-ND 4.0) licence. Full details of this licence are available at: https://creativecommons.org/licenses/by-nc-nd/4.0/

\section{LICENCE}

CC BY-NC-ND 4.0

\section{REPOSITORY RECORD}

Van Kessel, Stijn. 2019. "The Populist Cat-dog: Applying the Concept of Populism to Contemporary European Party Systems”. figshare. https://hdl.handle.net/2134/16890. 


\title{
The populist cat-dog. Applying the concept of populism to contemporary European party systems.
}

Stijn van Kessel (Loughborough University)

Accepted for publication on 18 May 2013

Final version in: Journal of Political Ideologies, 19 (1), 2014, pp. 99-118.

\begin{abstract}
Populism is a frequently used yet problematic concept; the term is often ill-defined and randomly applied. While these problems have been widely acknowledged, this paper argues that there are still issues with the way populism tends to be used, even if a sound definition is provided. This relates to the fact that it is often not clear whether populism is used to refer to an ideological feature of an exclusive category of political parties or whether populism is seen as a type of discourse which can be expressed by any political actor. In order to illustrate the difficulties with regard to the application of the term populism, several 'hard' cases of populism across Europe are discussed. The paper argues that in order to stimulate a more accurate use of the term, observers should be explicit not only about the meaning of populism, but also about the form in which it manifest itself.
\end{abstract}

Key Words: Populism, Party Families, Concept Formation, Europe. 


\section{The populist cat-dog. Applying the concept of populism to contemporary European party systems.}

\section{Introduction}

Populism is a concept which has frequently emerged in recent scholarly contributions and which has also attracted much attention outside of academia. Although the term has been used extensively, the concept is problematic due to the unsystematic (pejorative) use and the fact that populism is often ill defined. ${ }^{1}$ The term is regularly used to denote anti-incumbent rhetoric or to describe politicians who pander to public opinion, but definitional precision tends to be lacking. Yet, as this paper will show, also when a clear definition is provided, there are problems related to the way the concept is applied in order to describe political phenomena. Since the term has been used so widely, it is necessary to stimulate a more accurate use of the concept. This paper takes the view that this is even more important since (the surge of) populism can be seen as an indicator for the legitimacy of a political regime and the state of representative democracy in general. ${ }^{2}$ The surge of populism is a sign that a democratically elected regime is seen to be unresponsive to the demands of a certain segment of the population.

Even though the term populism is used randomly, and even though the concept can certainly be considered to be an 'essentially contested' concept, $^{3}$ the scholarly debate about the characteristics of the concept is well developed. It is even possible to notice something of a consensus on some of the core features of populism within the political science literature, ${ }^{4}$ at least among those who aim to define the concept carefully. Unfortunately, even if a clear definition is provided, conceptual problems arise when the concept of populism is applied to describe the characteristics of political actors, and political parties in particular. It is these problems related to the application of populism which are central to this paper. When the term is used, it is often not clear, or 
made explicit, whether a reference is made to a specific delineated subset of political parties or whether populism is seen as a certain discourse, which can essentially be voiced by any political actor. Thus, besides the unsystematic use of populism, or the absence of a clear definition, the lack of uniformity in the application of the term is an important reason as to why the concept of populism resembles the concept of, what Giovanni Sartori calls, a cat-dog. ${ }^{5}$ The term is used to describe political actors that in fact cannot be placed in a single category.

Starting out from a minimal definition of populism, this paper first aims to point out the difficulties of using populism in a meaningful way in order to discriminate between political actors. Specifically, using the words of Allan Sikk, the paper shows that it is hard to distinguish between populism as a 'classifier', which refers to a circumscribed universe of populist actors, and populism as a 'descriptor', which denotes (more fleeting) expressions of populist discourse in political systems. ${ }^{6}$ Secondly, the paper seeks to investigate whether the cat-dog problem can be tackled by choosing the most appropriate strategy of concept formation and following this strategy consistently.

In order to illustrate the problems with regard to the application of populism, this paper touches on various alleged instances of populism throughout Europe, with a particular focus on political parties. The European continent is home to both longestablished democracies in which we can point out a, more or less uncontested, set of populist parties as well as relatively new democracies (in post-communist countries), where applying the concept in a useful way seems less straightforward. Classification issues, however, are by no means limited to these latter countries and the main focus in this paper will be on several 'hard' cases of populism across the continent; instances which raise doubt about the discriminating power of populism. ${ }^{7}$ Further, it is particularly in the European literature where progress towards definitional consensus has been realised with regard to the concept of populism. ${ }^{8}$ This paper shows that, despite consensus on key constituent components of populism, the application of the concept can still be problematic. 
The following section first discusses the varying ways in which the concept of populism is applied to political systems in the existing literature. The subsequent section discusses which strategy of concept formation seems most appropriate when the aim is to apply populism in a useful and accurate manner. It is argued that the 'classic model' of concept formation is the preferable option. ${ }^{9}$ Yet, by means of several hard cases of populism, the succeeding section shows that using a clear minimal definition of populism does not necessarily guarantee a meaningful and accurate application of the concept. The discussion of these cases is centred on two main issues. A first key issue is that populist discourse can be used to various degrees and that it is unclear when a political movement party can be classified as a 'full' instance of populism. The second, often related, difficulty is that populist discourse can be added and removed from the repertoire of political actors quite easily, so that a potential universe of populist parties can become rather changeable throughout time. The paper argues that both these issues are particularly apparent in post-communist democracies in Central and Eastern Europe. The final part of the paper argues that it is useful to conceive of a ladder of abstraction of populist manifestations, which sheds light on the conceptual problems discussed in this paper. ${ }^{10}$ On the basis of this, several recommendations for applying the concept of populism are presented.

\section{The concept of populism and its application}

In the past decades various definitions or descriptions of populism have been provided in which similar features recur. ${ }^{11}$ While the ground-breaking edited volume of Ghiţa Ionescu and Ernest Gellner was still marked by the absence of an agreed definition of populism, various definitions have been provided in recent years which showed important similarities. ${ }^{12}$ Thus, many political science scholars who specialise on the topic of populism tend to refer to a similar set of core components when they use the concept. 
These are outlined particularly clearly by Ben Stanley, who identified the following four, distinct but interrelated, features:

- The existence of two homogeneous units of analysis: 'the people' and 'the elite'.

- The antagonistic relationship between the people and the elite.

- The idea of popular sovereignty.

- The positive valorisation of 'the people' and denigration of 'the elite'. ${ }^{13}$

It has to be noted that these, or similar, components appear in the contributions which focus on the ideational characteristics of populism. Other authors have placed more emphasis on the organisational features of populism and personalistic or 'charismatic' leadership in particular. ${ }^{14}$ Here, however, populism is essentially considered to be a set of ideas. Following Mudde and Rovira Kaltwasser, populism might have an 'elective affinity with certain organizational aspects' such as charismatic leadership and unmediated representation, but these should not be seen as defining properties of populism. ${ }^{15}$ Populism can be expressed in different organisational shapes and forms. ${ }^{16}$

The four core components identified by Stanley provide the basis for the discussion on the way the concept is applied in the academic literature. Even if scholars would agree on a single definition, it remains unclear (or disputed) how populism manifests itself in political systems. As outlined in the introduction, it is debated whether populism can be seen as core component of a circumscribed 'universe' of political actors or whether it merely constitutes a type of discourse which can be applied by any political actor.

Recent contributions appear to suggest that populism is more than an easily disposable rhetoric, in describing populism as an ideology, albeit a 'thin' or 'thin-centred' one. ${ }^{17}$ Following Michael Freeden, a thin-centred ideology is an ideology 'that arbitrarily severs itself from wider ideational contexts, by the deliberate removal and replacement of concepts'. ${ }^{18}$ This implies that populism as a thin-centred ideology does not provide a comprehensive programme of how a particular society should function. Parts of existing, more wide-ranging, ideologies can and should be added to the populist core. In the 
words of Ben Stanley, populism 'is diffuse in its lack of a programmatic centre of gravity and open in its ability to cohabit with other, more comprehensive, ideologies'. ${ }^{19}$ This is similar to Taggart's assertion that populism lacks core values and that it is 'chameleonic' since the ideological colour it adopts depends on context and the values of the 'heartland' it appeals to. ${ }^{20}$

According to Margaret Canovan, however, the lack of an programmatic centre of gravity actually makes it difficult to speak of a populist ideology; 'attempts to define populism in terms of any such ideology fail, because in another context the anti-elitist mobilization concerned may be reacting to a different ideological environment'. ${ }^{21}$ It is, according to Canovan, best to build a descriptive typology 'which clarifies the ways in which the term is used while being spacious enough to do justice to the diversity of the movements and ideas concerned'. ${ }^{22}$ Proponents of the 'thin ideology' interpretation of populism have responded to this claim by arguing that populist actors across the globe may be dissimilar as far as their specific policy positions are concerned, but that they still share a fundamental set of core traits. Thus, in the words of Stanley:

the lack of an acknowledged ideology is not the same as the lack of an ideology: the absence of a common history, programme and social base, whilst attesting to populism's 'thin' nature, does not warrant the conclusion that there is no coherence to the collection of concepts that comprise populist ideology. ${ }^{23}$

Perceiving populism as a (thin-centred) ideology seems to imply that there are political actors that have this populism as a defining ideological characteristic. It would then, in principle, be possible to distinguish populist from non-populist political actors. Indeed, in the literature authors often speak of 'populist parties' or party families for which populism is a core component. Cas Mudde, for instance, treats populism as a core element of the populist radical right and a few other party families. ${ }^{24}$

Yet populism is not always treated as a 'fixed' element of a particular type of party or politician. Kurt Weyland, for instance, explicitly defines populism as a political strategy and considers populism to be a tool for a leader to seek and exercise power. ${ }^{25}$ 
Hans-Georg Betz similarly asserts that one can see populism as a political strategy; a rhetoric 'designed to tap feelings of ressentiment and exploit them politically'. ${ }^{26}$ Jagers and Walgrave, in turn, speak about 'thin' populism - as opposed to the 'thick' variant which has more defining properties - as 'a communication style of political actors that refers to the people'. ${ }^{27}$

This line of reasoning implies that the use of populism is not necessarily confined to a particular type of movement or party. Jagers and Walgrave even add that also interest group representatives and journalists may use the populist communication style. ${ }^{28}$ Established politicians, who are normally at the receiving end of populist critique, can be associated with populism too. Cas Mudde actually argued that the emergence of the radical populist parties in Western Europe has led mainstream parties to use populist methods themselves as a response to the challenge of populist actors, leading to the dawn of a populist Zeitgeist. ${ }^{29}$

The fact that there are different perceptions about how populism manifests itself is not necessarily problematic if populism is defined in a careful way. It seems reasonable to argue that populism can occur in various forms (e.g. style, strategy and lasting ideology) and that the expression of populist discourse is not confined to a particular set of political actors. As a matter of fact, recent contributions have measured the degree of populism in the discourse of political parties, by considering party manifestos, speeches or party political broadcasts. ${ }^{30}$ In doing so, the question of whether populism is an ideology, strategy, communication style or something else, might not be very important.

Still, there are reasons why the concept of populism resembles the concept of a cat-dog. Following the analogy of Giovanni Sartori, a cat-dog is an animal that does not exist in reality, but biologists might make the mistake to lump together cats and dogs in one category because the animals show particular similarities. ${ }^{31}$ Populism is similar to a cat-dog; the term is used to describe political phenomena and actors that actually do not belong in the same category. This will be discussed in the following section, which also outlines the most appropriate concept-building strategy for populism. 


\section{The cat-dog and concept-building strategies}

There are three main reasons as to why populism is a cat-dog concept. It is the third reason, related to the application of the concept, which is central to this paper, but it is worth mentioning the first two as well. The first reason is the random use of populism due to the lack of a clear definition, which leads to the erroneous inclusion of many actors under the header of populism. ${ }^{32}$ The second reason is that, when a definition is provided, its components are often applied to cases too loosely. A result is that the concept of populism becomes 'stretched' and that too wide a variety of political phenomena become associated with populism. ${ }^{33}$ The risk of concept stretching becomes greater when scholars introduce different forms of populism which denote some sort of distinction between 'full populism' and 'semi populism'. An example is the previously mentioned concept of 'thin populism' introduced by Jagers and Walgrave: 'a communication style of political actors that refers to the people'. ${ }^{34}$ When comparing this definition to the four core concepts of Stanley, this definition arguably bears some resemblance to 'the idea of popular sovereignty' component, but to none of the others. Even if it concerns a definition of a 'thin' variant of populism, it is questionable whether we truly measure something related to populism in the first place when we would apply it.

More generally, if one would shop selectively in the list of populist core components, applying the concept to cases that do not comply with all four features outlined in Stanley's article for example, the risk is that populism becomes associated with any kind of opportunistic appeal to 'the people' or anti-establishment criticism. This would seriously weaken the discriminating power of the concept of populism, since such statements appear to be used by many political actors. For this reason, it is argued here that populism is best treated as a 'classical' concept. ${ }^{35}$ This requires a minimal definition, which includes the necessary and jointly sufficient defining properties. ${ }^{36}$ It is only the combination of all populist core components, or 'constitutive dimensions' in the words of Gary Goertz, that truly defines a phenomenon, or a political actor, as populist. ${ }^{37}$ 
Alternative strategies of concept formation would be the 'family resemblance' approach and the creation of 'radial categories'. ${ }^{38}$ The latter strategy entails the creation of a central subcategory which can be considered as a 'full' instance, because it incorporates all possible components of a concept. The concept, however, may still be used for cases which lack some of these components. Collier and Mahon use the example of the concept of 'mother'. ${ }^{39}$ Even if a woman is not the genetic mother of a child, and hence does not belong to the central subcategory, she might still be categorised as a 'nurturing mother' or a 'stepmother'. The family resemblance structure is even more flexible, in that it contains no necessary defining properties. ${ }^{40}$ The absence of one of the concept's properties can be compensated by the presence of another.

These approaches, however, are not suitable for the concept of populism. None of the four components outlined above can be left out, or substituted, without deriving the concept of its actual meaning and causing unwelcome concept stretching. For instance, if the concept is applied to party politics, leaving out the 'appeal to popular sovereignty' component would lead to the inclusion of parties with an anti-establishment, but not so much populist character, or, even worse, all opposition parties which happen to rail against the governing elite of the day. A reference to popular sovereignty only, on the other hand, is not necessarily connected with the populist notion that there is a normative distinction between 'the people' and 'the elite'. ${ }^{41}$ If the (often implicit) conception of the homogeneity of 'the people' is left out of the definition, the antipluralist character of populism would be ignored. ${ }^{42}$

Even if a more stringent minimal definition of populism is applied, there still is a third cat-dog problem, which is the problem central to this paper. The problem is related to what Sartori calls 'degreeism': 'the abuse (uncritical use) of the maxim that differences in kind are best conceived as differences of degree, and that dichotomous treatments are invariably best replaced by continuous ones'. ${ }^{43}$ In the case of populism, the problem of degreeism is not necessarily related to the properties of the concept itself, as it is possible to determine whether a single expression is either populist or not by means of a minimal definition. The problem lies more in the fact that it is unclear to 
what extent a political actor should use populist expressions in order for it to be considered a 'full' case of populism.

As discussed, it seems reasonable to accept that actors can use populist discourse to a certain extent. Political parties, for instance, may apply populist expressions to varying degrees (across time) in their campaign rhetoric or in their manifestos. In the words of Stanley:

At any given point, certain parties and social movements will be 'more populist' than others, in that populism is a more salient aspect of their appeal. Some may retain over time a consistent combination of populism and another, full ideology. Others may hitch their populism to a variety of passing ideological bandwagons. Still others may keep to a consistent full ideology with a waxing or waning populist element. Finally, in some cases they may exhibit no particular ideological consistency, thin or full. ${ }^{44}$

However, the fact that populism can manifest itself in different degrees and that populism is not necessarily an enduring core feature of political actors makes it difficult to conceive of an exclusive category of 'populist parties'. The problem in the literature is that there are many cases which are frequently branded as 'populist parties', but which do not seem to fully meet the definitional criteria previously outlined (throughout time). The following section illustrates this problem by means of several 'hard', or contestable, cases of populism throughout Europe.

\section{Hard cases of populism}

There are political parties whose populist nature seems more or less undisputed. These include 'classic' examples of Western European populist radical right parties, such as the French Front National, the Belgian Flemish Interest, the Austrian Freedom Party and the Italian Lega Nord. ${ }^{45}$ It thus appears to be possible to identify a more or less undisputed set of parties for which populism is a defining feature throughout time. This paper will, 
however, focus on several 'hard' cases of populism which illustrate the problems related to the application of the concept. These cases are partly selected on the basis of results from country expert questionnaires, which were carried out as part of a larger research project. The selected cases were those that attracted particular disagreement among the experts as far as questions about their populist character were concerned. The discussion is centred on two, distinct but often related, issues: the fact that some actors only seem populist to a certain extent and that some actors do not consistently voice populist discourse over time. Particular attention will be paid to cases in Central and Eastern Europe where both these issues are particularly apparent.

\section{Populist...but to a certain extent}

As has been noted above, problems with classification arise because it is not clear to which degree a political actor has to voice populist discourse in order to be considered as a 'full' case of populism. This problem can be illustrated well by using a study of Teun Pauwels, who has applied quantitative text analysis to measure the degrees of populism in the internal and external party literature of Belgian parties, on the basis of key words capturing (normative) references to 'the people' and 'the elite'. ${ }^{46}$ In the analysis, the Flemish Interest scored very high on the populism barometer, along with a smaller 'neoliberal populist' party List Dedecker (later renamed Libertarian, Direct, Democratic, LDD). ${ }^{47}$ This is rather unsurprising, as there has been little discussion about the populist nature of both parties. In third place on the populism scale, came a less usual suspect: the New Flemish Alliance (N-VA), the successor of the Flemish nationalist People's Union. This conservative party with a strong appeal to Flemish nationalism became the largest party in Flanders (and in the national parliament) after the federal election of 2010. Pauwels accounts for the high populism scores of the N-VA by referring to the party's critique of the allegedly unrepresentative francophone elite on the federal level and, on the basis of his findings, describes the N-VA's discourse as 'moderately populist'. ${ }^{48}$

The results from the analysis, however, do not seem to provide a very clear cutoff point between 'full' and 'moderate' populist parties. Pauwels finds that, on average, 
16 per cent of LDD's ideology was 'devoted to populism', while the equivalent figure for the Flemish Interest was 12 per cent. With a figure of just over 10 per cent, the N-VA did not trail far behind, and based on these findings it appears hard to draw a clear line between the three parties. As the Belgian case shows, measuring degrees of populism clearly does not directly lead to a solution as far as problems of classification are concerned. Even if it is not the purpose of the author to use the concept of populism in order to classify parties dichotomously (as either populism or not), it still is not straightforward how we should interpret meaningfully the differences in the degrees of populism between political actors. In this case, why should the N-VA be referred to as only 'moderately' populist when it only voices populist rhetoric to a slightly lower degree than the Flemish Interest?

While it can already be difficult to apply the concept of populism to political parties when they are perceived as unitary actors, it may become even more complicated if we consider intra-party dynamics as well. This is illustrated by the case of Silvio Berlusconi's conservative centre-right party Forza Italia, which later merged into the People of Freedom party (Il Popolo della Libertà, PdL). In this case, it is difficult to determine to which degree populism was a feature of the parties because of the discrepancy between the official programme of the party and the rhetoric of its leader. Berlusconi himself has been known for his dissociation from the 'corrupt and inefficient elite' and his eagerness to 'proclaim himself as the interpreter and defender of the popular will'. ${ }^{49}$ Marco Tarchi, however, has argued that Forza Italia, unlike its radical regionalist partner Lega Nord, could not truly be considered as a populist party, because the expression of populism was 'entirely delegated to the leader, who has made it a trademark of his political style, but not a source of ideological inspiration' ${ }^{50}$ Indeed, populist anti-establishment passages were not that widespread in official party documents and, as Carlo Ruzza and Stefano Fella found, even waned after the turn of the $21^{\text {st }}$ century. ${ }^{51}$ While it is thus possible to argue that Berlusconi himself was a populist figure, it is questionable whether Forza Italia in its entirety was as well. 
Be that as it may, the concept of populism has frequently been used to describe Forza Italia. ${ }^{52}$ There is also a good case for this in view of Berlusconi's dominant role within the party organisation. Things got ostensibly more complicated, however, when in March 2009 Forza Italia officially merged with other, non-populist, parties to form The People of Freedom party. Even though Berlusconi was also the central figure within the new party, the leader of its main partner, the National Alliance (Alleanza Nazionale, AN), 'continued to reiterate the distinctive and less populist profile of the AN element'. ${ }^{53}$ While AN party leader Gianfranco Fini left the party in July 2010 and formed a new party afterwards, it remains difficult to judge whether The People of Freedom party was truly populist during the short-lived partnership between the two leaders. Similar to the case of Forza Italia, a verdict largely depends on the extent to which the PdL is perceived as a personal project of its populist leader, Silvio Berlusconi.

Berlusconi's parties may be somewhat idiosyncratic cases and it is not surprising that they attract scholarly disagreement about how to describe them. But they do illustrate well the difficulty of applying the concept of populism. It is possible for individual leaders to adopt a populist discourse, whereas the party as a whole shows little populist characteristics if one looks at formal party documentation or the discourse of other party members. This discrepancy is possible due to the thin-centred nature of populism and the fact that populism is not necessarily related to particular policy positions. As long as the populist leader shares the same policy goals as the essentially non-populist party, this does not necessarily threaten the (ideological) cohesiveness of the organisation. It does make life rather hard, however, for the scholars seeking to conceive of an exclusive category of populist parties.

\section{Populist...but not consistently across time}

As the previous examples have shown, populism is difficult to apply in some cases because parties use populist discourse only to a certain degree or because populism is a feature of their leader's rhetoric but not so much of the party as a whole. A different, but 
potentially related, issue is that populism is not necessarily a key feature of political actors throughout time.

A case in point is the British National Party (BNP). Founded in 1982, the BNP descended from the, electorally rather insignificant, neo-fascist National Front. Particularly after the turn of the $21^{\text {st }}$ century the party aimed to cultivate a legitimate image by moving away from overt biological racism and by emphasising more commonplace 'local community' issues. $^{54}$ In the 2005 and 2010 general election manifestos the party also embraced democracy, whilst at the same time explicitly rejecting totalitarianism. ${ }^{55}$ The BNP also expressed a clear populist discourse by this time, combining a strong anti-establishment rhetoric with an explicit appeal to 'ordinary British folk'. ${ }^{56}$ The party also claimed that:

It is the 'average' man and woman who suffers from the failings of our politicians to grasp the issue and restore genuine democracy (...) The British National Party exists to put an end to this injustice. We will return power to the men and women of Britain, the taxpayers, pensioners, mums and dads and workers. ${ }^{57}$

Over the years, the BNP has thus arguably shifted from one ideology to another: from fascism to (radical right-wing) populism. It has been argued, however, that this ideological transformation merely represented an opportune change of clothing in order to become more electorally credible, instead of a true break with the past. ${ }^{58}$ If the BNP is still perceived to be a neo-fascist party in essence, it is debatable whether the BNP can be considered as a populist party at the same time, since populism and fascism can be seen as mutually exclusive ideologies. Fascists envision a totalitarian, hierarchically organised and organic state in which the people serve as mere parts of a larger whole. ${ }^{59}$ Populism, on the other hand, glorifies the ordinary people within the community, and not the state apparatus as such. ${ }^{60}$ Fascism, like other forms of right-wing extremism, is also anti-democratic. ${ }^{61}$ Populists, on the other hand, explicitly stress the desire for popular sovereignty and claim that the will of the people should be the ultimate source of legitimacy. ${ }^{62}$ The case of the BNP thus shows that it is not always possible to label a 
party as 'populist' throughout its whole existence, but also that it can be problematic to associate a party with populism if its original ideology appears to be at odds with the populist core components.

Thus far, only contestable cases of populism on the 'right', understood in socioeconomic and/or cultural terms, have been discussed. The Dutch Socialist Party, on the other hand, is a hard case on the socio-economic left. The party was founded in the 1970s, closely associating itself with Maoism, but only entered parliament in 1994. By this time, the party had gradually moved away from its communist roots and could better be described as a 'social-populist' party. ${ }^{63}$ Following March and Mudde, socialpopulist parties 'no longer profess to be the 'vanguard' of the proletariat, but rather the vox populi, they place particularism before internationalism, with a much less theoretical and more inclusive style than hitherto'. ${ }^{64}$ Besides its appeal to the vox populi, The SP railed against the capitalist elites and the politicians who were associated with it. The anti-establishment character of the party was evident during the 1990 s, exemplified by the slogan it applied: 'vote against, vote SP'.

In more recent years, however, the SP seems to have downplayed this antiestablishment image to a large extent - in 2002 its slogan had remarkably changed to 'Vote for, vote SP'. De Lange and Rooduijn (2010: 7) have furthermore shown that the anti-elitist rhetoric in SP manifestos gradually evaporated; in 1994 anti-elite references were found in 17 per cent of the paragraphs, while this percentage dropped to a mere 1.5 per cent in $2006 .{ }^{65}$ Bearing in mind the lack of a strong 'denigration of the elite' in the discourse of the SP in more recent years, there is a good case for now classifying the SP as an 'ordinary', albeit somewhat radical, social-democratic party. ${ }^{66}$ This does not necessarily lead to conceptual confusion if the rhetorical, or perhaps even ideological, change of the SP is acknowledged and when scholars seize to use the label of populism in order to classify the party. However, once a party or politician has been labelled as 'populist', this label appears likely to stick irrespective of whether the rhetoric of the actor still complies with the definition of populism. Both in the vernacular and academic sphere, the SP is still regularly referred to as a 'populist party'. ${ }^{67}$ 
A final point to make is that the 'social-democratisation' of the Dutch Socialist Party can be related to the party's eagerness to join a governing coalition, which caused it to voice less radical critique of potential coalition partners. Along similar lines, it has been argued that it is typical for populist parties to lose their anti-establishment character whilst in office. ${ }^{68}$ If they possess governing power, it is a challenge for populist parties to still distance themselves from 'the elite' in a convincing way. Then again, in the literature on Latin American populism the term actually tends to be associated with leaders who wield great executive power. ${ }^{69}$ In Europe, too, some populist parties seem able to retain their populist character in office. Albertazzi and McDonnell, for example, show that the Italian Lega Nord 'succeeded in presenting itself simultaneously as both 'the opposition within government' and a driving force behind high-profile areas of government policy' and thus 'successfully walked the populist tightrope of being seen to have 'one foot in and one foot out' of government'. ${ }^{70}$ The Swiss People's Party (SVP) is another example. Following Andrej Zaslove, the SVP managed 'to present itself as a party of government and a party in opposition at the same time'. ${ }^{71}$

Although there are instances of parties which have been consistently characterised by their populist discourse over time, even after they entered office, the thin ideological nature of populism warrants that populism can more easily be disposed of, or taken on board, by political actors than other 'full' ideologies. This makes it difficult to judge which political parties can be considered to form part of a clearly delineated universe of 'populist parties'. What is more, the nature of such a universe is changeable itself. The next section will outline how this problem is particularly evident when we move beyond the Western European political sphere.

\section{Populism in post-communist Europe}

Due to the relatively recent transition to democracy in post-communist countries, archetypical cases of populism, such as the French Front National and the Belgian Flemish Interest, are lacking in the Central and Eastern part of the continent. After the fall of communism, party systems in post-communist Europe have been marked by the 
rise and fall of numerous new parties and the ideological appeal of these parties has often been changeable. Moreover, many of these new parties played into the widespread discontent with political elites. As Mudde has argued, for instance, many parties in postcommunist countries have gone through a populist radical right phase. ${ }^{72}$ Due to these reasons, post-communist countries pose a particular challenge when it comes to using the concept of populism to distinguish between political actors in a meaningful way. A study of Deegan-Krause and Haughton, for example, showed that populism was widespread within the Slovakian party system, but that parties tended to lose their populist traits once in office or once their lifespan had increased. ${ }^{73}$ Parties such as the Movement of Workers of Slovakia (ZRS), the Party of Civic Understanding (SOP), Alliance of the New Citizen (ANO) and Direction (Smer), could therefore all be considered as populist parties, but only during a particular period of time.

Distinguishing between populist and non-populist parties in post-communist Europe is further complicated by the presence of a more general anti-political mood after the transition to democracy. ${ }^{74}$ The issue of corruption has been electorally salient in many post-communist countries in particular, which resulted in the formation of many new parties with an anti-incumbent message calling for cleaner politics. Peter Učeň referred to several such parties in Central and Eastern Europe, which were mainly characterised by their anti-establishment rhetoric, as 'new centrist populists'. ${ }^{75}$ It is questionable, however, whether such parties could all truly be associated with populism in the sense that they complied with all the components of a more stringent minimal definition. In a paper discussing several parties in the Baltic States, which were all newly founded and marked by their anti-incumbency and anti-corruption messages, Allan Sikk rightly warns that simply equating such parties' critical style with populism leads to further concept stretching. ${ }^{76}$

Yet also when following a stricter strategy of concept formation, applying populism as a 'classifier' in Central and Eastern Europe can be daunting. This can be illustrated by means of the case of Law and Justice in Poland (Prawo i Sprawiedliwość, PiS). In Poland, too, continuing practices of clientelism and corruption during the 1990s 
and early 2000s fuelled a growing anti-establishment mood. ${ }^{77}$ As a result, antiestablishment rhetoric was widespread during election campaigns and PiS was one of the parties which clearly aimed to capitalise on this. The party, eventually spearheaded by the twin brothers Jarosław and Lech Kaczyński, emerged from a governing centre right alliance, which largely fell apart in 2001. The Kaczyński brothers were hardly usual suspects to be branded as populist outsiders, since both brothers had been active in the highest echelons of Polish politics in the years after the transition to democracy.

It was only from the electoral campaign of 2005 onwards that PiS became truly associated with populism, when the party re-profiled itself ideologically. Radoslaw Markowski even spoke of a 'spectacular change' of Law and Justice from a 'fairly typical conservative party' into a 'radical nationalist, and visibly populist-socialist one'. ${ }^{78}$ The party sharpened its anti-establishment rhetoric, explicitly referring to a 'Fourth Republic', which was supposed to bring an end to the Third Polish Republic and to start a new era of clean and moral government. According to Ben Stanley, the party now portrayed itself 'as representative of an ordinary, authentic, legitimate 'people' against an illegitimate and usurping elite', and became an example of 'populism in power' after it entered government'. ${ }^{79}$

Even though it is justifiable to apply the populist label to Law and Justice since the 2005 election campaign, there is some disagreement about whether the party truly underwent a 'spectacular change', or whether the new course was merely a shift in emphasis. ${ }^{80}$ Fighting corruption, for instance, had been at the core of the party's programme from the outset. ${ }^{81}$ If the case is made that the programme of Law and Justice has been marked by more continuity than change throughout the years, one may wonder whether it is justifiable to place the party into a different category (of populist parties) after 2005, or whether it is better to merely speak of a greater degree of populism in its discourse without reclassifying the party.

More generally, in view of the relative newness and fluidity of party systems in post-communist countries it is often not easy to distinguish between a real political establishment and populist parties challenging it. Widespread dissatisfaction in many of 
these countries created a fertile breeding ground for populism, but this populism was not confined to specific political parties, as has often been the case in Western Europe. Therefore, identifying a clearly circumscribed universe of 'populist parties' in postcommunist countries has, up until now, been rather difficult.

Having touched on examples of hard cases of populism throughout Europe, the next section discusses how to best make sense of the concept of populism, as it manifests itself in European countries.

\section{Dissecting the populist cat-dog}

As has been argued, populism can be seen as a cat-dog concept, even if a clear definition of populism is provided. Certain political actors, parties in particular, are placed in a single category under the header of 'populism', even though this does not always seem justifiable. This tends to happen when the definition of populism is applied too loosely. Yet also when populism is applied more stringently as a 'classical' concept, the cat-dog problem persists. This relates to the fact that political actors can voice populist rhetoric to different degrees (across time). What is problematic is that observers using the concept are often not explicit about whether they intend to refer to a particular delineated subset of populist actors (e.g. populist politicians or political parties) or whether they mean that the actor is expressing populist discourse in a more fleeting sense.

One way to deal with this is to be clearer about the way populism is seen to manifest itself when a reference is made to a particular actor. In order to illustrate this point we can use Sartori's idea of the ladder of abstraction. ${ }^{82}$ The basic idea is that concepts higher on the ladder have fewer properties and are, therefore, applicable to more cases. In other words, they have a low intension and a high extension. Concepts lower on the ladder have a higher intension (i.e. more properties) and a lower extension (i.e. they are applicable to fewer cases). 
This inverse relationship between intension and extension does not always apply if one, for instance, uses radial concepts. ${ }^{83}$ The idea of the ladder can be used, however, when one speaks about the different manifestations of populism; using populism either as a 'classifier' or as a more loose 'descriptor' essentially involves making a judgement about which level of abstraction populism manifests itself on (see Figure 1). At the top of the ladder, we find expressions of a discourse which complies with the minimal definition of populism. Populism, in this sense, does not have to denote more than a rhetorical strategy used by any political actor. The extension of 'populist discourse' is, therefore, rather high. This application of populism is particularly suitable for cases in postcommunist countries where populist discourse tends to be used in a rather fleeting sense.

\section{***Figure 1 about here***}

When our aim is to use populism to describe party politics, taking a step down would lead us to the level of 'populist parties'. These are parties which have populism as a lasting defining feature, which sets them apart from parties whose politicians use populist rhetoric only sporadically or for a short period of time. By moving this step down we are not adding properties to the concept of populism as such - following the traditional Sartorian way - but we are increasing the intension of the concept by only accepting cases in this category which express populist discourse consistently throughout time. Populism needs to constitute an important raison d'être for parties in this category.

Particularly if we speak about the European context, it can make sense to make one further step down by distinguishing various party families which have populism as a defining feature. Due to their 'thin centred' or 'chameleonic' character, populist parties can differ as far as their substantive policy positions are concerned. The minimal definition of populism can be expanded, however, by adding additional properties to describe various kinds of populist party families. ${ }^{84}$ As a result, we can end up with categories such as 'populist radical right', 'neoliberal populism' and 'social populism' if we 
move to the bottom of the ladder. ${ }^{85}$ It is important to note that, despite ideological differences, populism can still be seen as an important core component of these various parties. This is also why it is still useful to use the more abstract category of populist parties in general. It might be a thin core that binds populist parties, but this core might still tell us a lot about their behaviour and performance. ${ }^{86}$

In any case, bearing in mind, and being explicit about, different levels of abstraction when applying the concept of populism is a first step to stimulate a more accurate use of the concept. Scholars and other observers should not be too quick to conclude that actors using populist rhetoric can also be classified as populists. On the basis of the ladder and the earlier discussion on concept formation, the following recommendations can be made that lead to a more accurate use of the concept of populism and the adjective 'populist' in particular:

- Do not use the adjective of populism when a case only complies with some of the (necessary and jointly sufficient) components of populism (e.g. when a party merely presents itself as radical outsider).

- Use populism as a 'descriptor' when a political actor expresses discourse that complies with a minimal definition of populism. Stay on this level of abstraction if populism is not a lasting constituent feature of the political party or movement this actor is representing, or when the study merely means to analyse degrees of populism in general. In these cases, refer to the expressions of the actor being populist, not to the nature of the actor itself.

- Use populism as a 'classifier' when populism is an essential characteristic of a political actor and when the study refers to a case within an exclusive category of populist actors (such as 'populist parties'). Populist discourse ought to be voiced consistently by those actors for an extended period of time.

When applying the concept of populism to party politics, these recommendations can form the basis of a more critical assessment of whether or not a party is part of an 
exclusive category of 'populist parties'. That is not to say that disagreements about certain hard cases of populism, such as the ones discussed earlier in this paper, would automatically be resolved. A judgement whether or not to include cases such as the New Flemish Alliance, Forza Italia and Law and Justice into the category of 'populist parties' requires in-depth knowledge of the party's ideological characteristics and/or organisational structure. Then, a sensible choice about either inclusion or exclusion can be made. For example, on the basis of a more qualitative assessment of the party, Teun Pauwels recently argued that despite its use of anti-establishment appeals, the New Flemish Alliance could actually not be labelled as a populist party because of its elitist characteristics and lack of appeal to the vox populi. ${ }^{87}$ Silvio Berlusconi's parties, on the other hand, seem suitable for inclusion into the 'populist party' category. Following Duncan McDonnell, both the People of Freedom party and Forza Italia could be seen as 'personal parties' of their populist leader, when factors such as the party organisation, campaign strategies and intra-party power relations are considered. ${ }^{88}$

There still is the issue that certain actors, and parties such as the British National Party, the Dutch Socialist Party and Law and Justice in Poland, have either adopted or abandoned a populist discourse throughout time. This is not necessarily problematic if it is clearly mapped when populism became, or seized to be, a defining feature of those parties. On that basis, we can consider Law and Justice after 2005 as a full instance of populism, as populist discourse became not only part of its campaign rhetoric, but also of its ideological appeal whilst in government. At the same time, populism seized to be a defining feature of the Socialist Party's ideology after the turn of the $21^{\text {st }}$ century. Concerning the British National Party, a choice has to be made whether to consider its revamped, less extremist, discourse as a reflection of its 'real' ideology. If the rhetoric and political programme of the BNP is considered at face value, the party can be said to have moved from neo-fascism to populism at the start of the $21^{\text {st }}$ century. ${ }^{89}$

Measuring degrees populism can be a way to shed more light on borderline cases, provided that measurement is based on sound indicators and valid sources. When the aim is to apply populism as a 'classifier' on the basis of this measurement, it would also 
help if clear thresholds are set in order to determine how much populism a party, for example, has to express in order to consider it as a 'full' populist party. Then again, most studies measuring populism do not seem to have this aim, or even explicitly state that populism should only be seen in terms of degrees and not used as a 'classifier'. ${ }^{90}$ These studies, however, are not always entirely consistent in their argument. Rooduijn, De Lange and Van der Brug, for instance, take the 'degreeism stance' but still identify a set of parties which they refer to as 'radical right-wing populist parties' and 'radical leftwing populist parties', hence implicitly using populism as a classifier at the same time. ${ }^{91}$

This later example shows that it is important to be explicit and consistent about the position we take on the ladder of abstraction of populist manifestations. ${ }^{92}$ One cannot deny that populism can be used as a classifier and at the same time speak of 'populist parties'. Applying the adjective too carelessly leads to confusion about a potential universe of full populist cases, and we may end up comparing incomparable cases. We also risk doing this when we would use a more 'Goertzian' approach in which populism is considered to manifest itself on a continuum of gradations, distinguishing, for instance, between categories such as 'slightly', 'moderately' and 'very' populist parties. ${ }^{93}$ Besides the risk of creating more confusion about where to place specific instance of populism, it is questionable whether this approach would be of much analytical use in making sense of the phenomenon of populism, as expressed by political actors.

This paper therefore argues that it is most fruitful to be open to the idea that populism can manifest itself as a more loosely applied discourse, as well as an essential feature of certain populist politicians and parties. It is necessary that observers are explicit about the way in which they apply the term. Even though discussion about borderline cases will remain, this is a first step to come to a more accurate use of the concept. 


\section{Conclusion}

This paper has discussed problems associated with the application of the term populism, using various 'hard' cases throughout Europe to illustrate these problems. Conceptual confusion often stems from a lack of a sound definition. Yet, as this paper has argued, also when the term is defined more carefully, a 'cat-dog problem' remains. Many political actors are associated with populism, but not all of those seem to fit into the same category. An important reason for this is that populism can be used to refer to a particular discourse which can be expressed by any political actor as well as an ideological core feature of a delineated set of political parties. Observers are often not explicit about this distinction, and making this distinction becomes harder as political actors may also use populist rhetoric to different degrees (over time). This is particularly apparent in relatively young post-communist party systems, where party ideologies have been fluid and which have been marked by the arrival and demise of new political parties which often voiced an anti-incumbent message. Still, it makes sense to conceive of an exclusive category of 'populist parties'. Parties such as the Font National, Lega Nord and Flemish Interest cannot truly be characterised without taking their populist ideology into account and can, therefore, be distinguished from parties that use populism only sporadically.

In order to stimulate a more accurate use of the concept, the paper suggested treating populism as a 'classical' concept. Creating several subcategories of populism, and thereby treating populism as a radial concept, is a recipe for concept stretching and would derive populism of its actual meaning. Further, the paper suggested that observers need to be more explicit about how they apply the term and whether they use the concept as a more loose 'descriptor' or as a 'classifier' in order to refer to a case within a circumscribed universe of populist cases. The paper has introduced a ladder of abstraction of populist manifestations in order to clarify this suggestion. At a lower level of abstraction, populism is a suitable term to describe various parties for which populism is an ideological core component. At a higher level of abstraction, the concept may be 
used to spot trends in the expression of populist discourse by any political actor. It is important that observers are clear where they stand on the ladder in order to avoid confusion about the potential universe of populist cases.

Working on the basis of a sound definition, as well as being more explicit about the form in which populism is seen to manifest itself, may not automatically end discussions about borderline cases, but is a first step towards a more accurate application of the concept. This is important if it is accepted that the phenomenon of populism fulfils an important role, either as a threat to, or a corrective for, representative democratic regimes.

\section{Notes}

1 See T. Bale, S. van Kessel, and P. Taggart, 'Thrown around with abandon? Popular understandings of populism as conveyed by the print media: a UK case study', Acta Politica, 46(2) (2011), pp. 111-131.

${ }^{2}$ See for example Y. Mény and Y. Surel, 'The Constitutive Ambiguity of Populism', in: Y. Mény and I. Surel (eds.), Democracies and the Populist Challenge (Basingstoke: Palgrave, 2002), pp. 121; P. Taggart, 'Populism and the Pathology of Representative Politics', in Y. Mény and Y. Surel (eds.), Democracies and the Populist Challenge (Basingstoke: Palgrave, 2002), pp. 62-80; F. Panizza, 'Introduction: Populism and the Mirror of Democracy', in: F. Panizza (ed.), Populism and the Mirror of Democracy (London: Verso, 2005), pp. 1-31.

${ }^{3}$ See W. B. Gallie, 'Essentially contested concepts', Proceedings of the Aristotelian Society, 56 (1956), pp. 67-198; D. Collier, F. Hidalgo and A. Maciuceanu, 'Essentially contested concepts: Debates and applications', Journal of Political Ideologies, 11(3) (2006), pp. 211-246.

\footnotetext{
${ }^{4}$ A. Zaslove, 'Here to Stay: Populism as a New Party Type?', European Review, 16(3) (2008), p. 322.

${ }^{5}$ G. Sartori, 'Comparing and Miscomparing', Journal of Theoretical Politics, 3(3) (1991), pp. 243-257.
}

${ }^{6}$ A. Sikk, 'Parties and Populism', Centre for European Politics, Security and Integration Working paper, University College London, 2009-02 (2009). 
7 G. Sartori, 'Concept Misformation in Comparative Politics', American Political Science Review, 64(4) (1970), p. 1039.

${ }^{8}$ C. Mudde and C. Rovira Kaltwasser, 'Exclusionary vs. Inclusionary Populism: Comparing

Contemporary Europe and Latin America', Government and Opposition, available on CJO2012. doi:10.1017/gov.2012.11, p.3.

${ }^{9}$ See D. Collier and J. Mahon, 'Conceptual "stretching" revisited: Adapting categories in comparative analysis', American Political Science Review, 87(4) (1993), 845-855; Sartori op. cid., Ref 7.

${ }^{10}$ See Sartori, op. cit., Ref. 7, p.p. 1033-1053.

${ }^{11}$ See, for example, E. Shils, The Torment of Secrecy: the background and consequences of American security policies (London: Heineman, 1956); G. Ionescu and E. Gellner (eds.), Populism, its Meanings and National Characteristics (London: Weidenfeld and Nicolson, 1969); P. Taggart, Populism (Buckingham and Philadelphia: Open University Press, 2000); C. Mudde, 'The Populist Zeitgeist', Government and Opposition, 39(4) (2004), p. 543; D. Albertazzi and D. McDonnell, 'Introduction: The Sceptre and the Spectre', in: D. Albertazzi and D. McDonnell (eds.) Twenty-First Century Populism. The Spectre of Western European Democracy (Basingstoke: Palgrave MacMillan, 2008), p. 8.; K. Abts and S. Rummens, 'Populism versus Democracy', Political Studies, 55(6) (2007), p. 409.

${ }^{12}$ Ionescu and Gellner, ibid.; Mudde, ibid.; Albertazzi and McDonnell, ibid.; Abts and Rummens, ibid.

${ }^{13}$ B. Stanley, 'The Thin Ideology of Populism', Journal of Political Ideologies, 13(1) (2008), pp. 95-110.

${ }^{14}$ See, for example, K. Weyland, 'Clarifying a Contested Concept - Populism in the Study of Latin American Politics', Comparative Politics, 34(1) (2001), p. 14; K. Roberts, 'Populism, Political Conflict, and Grass-Root Organisation in Latin America', Comparative Politics, 38(2) (2006).

${ }^{15}$ Mudde and Rovira Kaltwasser, op. cit., Ref. 8, p. 8.

${ }^{16}$ See also M. Canovan, Populism, (New York and London: Harcourt Brace Jovanovich, 1981).

${ }^{17}$ Mudde, op. cit., Ref. 11; Abts and Rummens, op. cit., Ref. 11; Stanley. op. cit., Ref. 13; Mudde and Rovira Kaltwasser, op. cit., Ref. 8. 
${ }^{18}$ M. Freeden, 'Is Nationalism a Distinct Ideology?', Political Studies, 46(4) (1998), p. 750.

${ }^{19}$ Stanley, op. cit., Ref. 13, p. 100.

20 Taggart, op. cid. Ref. 11; P. Taggart 'Populism and representative politics in contemporary Europe', Journal of Political Ideologies, 9(3) (2004), pp. 274-5.

${ }^{21}$ M. Canovan, 'Trust the People! Populism and the Two Faces of Democracy', Political Studies, 47(1) (1999), p. 4.

22 M. Canovan, 'Two Strategies for the Study of Populism', Political Studies, 30(4) (1982), p. 550.

${ }^{23}$ Stanley, op. cit., Ref. 13 , p. 100.

${ }^{24}$ C. Mudde, 'Populist Radical Right Parties in Europe' (Cambridge: Cambridge University Press, 2007).

${ }^{25}$ Weyland, op. cit., Ref. 14, p. 12.

${ }^{26}$ H.-G. Betz, 'Conditions Favouring the Success and Failure of Radical Right-Wing Populist Parties in Contemporary Democracies', in: Y. Mény and Y. Surel (eds.), Democracies and the Populist Challenge (Basingstoke: Palgrave, 2002), p. 198.

27 J. Jagers and S. Walgrave, 'Populism as political communication style: An empirical study of political parties' discourse in Belgium', European Journal of Political Research, 46(3) (2007), p. 322 .

28 Jagers and Walgrave, ibid.

${ }^{29}$ Mudde, op. cid., Ref. 11, pp. 542-563.

${ }^{30}$ See for example Jagers and Walgrave, op. cid., Ref. 27, pp. 319-345; K. Hawkins, 'Is Chavez populist? Measuring populist discourse in comparative perspective', Comparative Political Studies, 42(8) (2009), pp. 1040-1067; K. Deegan-Krause and T. Haughton, 'Toward a more useful conceptualization of populism: Types and degrees of populist appeals in the case of Slovakia', Politics \& Policy, 37(4) (2009), pp. 821-841.; T. Pauwels, 'Measuring populism: A quantitative text analysis of Party Literature in Belgium', Journal of Elections, Public Opinion and Parties, 21(1) (2011), pp. 97-119; M. Rooduijn, S. de Lange, and W. van der Brug, 'A 
populist Zeitgeist? Programmatic contagion by populist parties in Western Europe', Party Politics, Advance online publication 20-04-2012.

${ }^{31}$ Sartori, op. cid., Ref. 5, p. 248.

${ }^{32}$ See Bale et al., op cid. Ref. 1.

${ }^{33}$ Sikk, op. cid., Ref. 6, p. 1.

${ }^{34}$ Jagers and Walgrave, op. cid., Ref. 27.

${ }^{35}$ In other contributions this approach is also taken. See Weyland, op. cit., Ref. 14; Sikk, op. cid., Ref. 6; Mudde and Rovira Kaltwasser, op. cit., Ref. 8.

${ }^{36}$ See G. Sartori, 'Guidelines for Concept Analysis', in: G. Sartori (ed.), Social Science Concepts (Beverly Hills: Sage, 1984), pp. 55-6.

${ }^{37}$ G. Goertz, Social Science Concepts. A User's Guide (Princeton: Princeton University Press, 2006).

${ }^{38}$ Collier and Mahon, op. cid., Ref 9.

${ }^{39}$ Collier and Mahon, ibid., p. 849.

${ }^{40}$ Goertz, op. cid., Ref. 37 , p. 7, p. 45.

${ }^{41}$ Mudde, op. cid., Ref. 11, p. 544.

${ }^{42}$ Mudde, ibid., p. 543-4; Mudde and Rovira Kaltwasser, op. cit., Ref. 8, p.6.

${ }^{43}$ Sartori, op. cid., Ref. 5, p. 248.

${ }^{44}$ Stanley, op. cid., Ref. 13, p. 108.

${ }^{45}$ See for example Mudde, op. cid., Ref. 24

${ }^{46}$ Pauwels, op. cid., Ref. 30.

47 T. Pauwels, 'Explaining the success of neoliberal populist parties: the case of Lijst Dedecker in Belgium', Political Studies, 58(5) (2010), pp. 1009-1029.

${ }^{48}$ Pauwels, op. cid., Ref. 30, p. 110. 
49 M. Tarchi, 'Italy: A Country of Many Populisms', in D. Albertazzi and D. McDonnell (eds.), Twenty-First Century Populism. The Spectre of Western European Democracy (Basingstoke: Palgrave MacMillan, 2008), p. 93.

50 Tarchi, Ibid., p. 86.

${ }^{51}$ C. Ruzza and S. Fella, Re-inventing the Italian Right. Territorial politics, populism and 'post-fascism (Oxon: Routledge, 2009), p. 131.

52 See for instance F. Raniolo, 'Forza Italia: A Leader with a Party', South European Society and Politics, 11(3) (2006), pp. 439-455; G. Pasquino, 'The Five Faces of Silvio Berlusconi: The Knight of Anti-politics', Modern Italy, 12(1) (2007), pp. 39-54; Ruzza and Fella, ibid.

53 Ruzza and Fella, ibid., p. 40.

54 See for instance M. Goodwin, New British Fascism. The Rise of the British National Party, (Oxon: Routledge, 2011).

55 See British National Party, Rebuilding British Democracy, general election manifesto (Welshpool: BNP, 2005), p. 9.

56 British National Party, ibid., p. 53

57 British National Party, ibid., p. 3.

${ }^{58}$ N. Copsey, 'Changing course or changing clothes? Reflections on the ideological evolution of the British National Party 1999-2006', Patterns of Prejudice, 41(1) (2007), pp. 61-82.

59 See for instance P. Hayes, Fascism (London: Allen and Unwin, 1973); S. Payne, Fascism. Comparison and Definition (Wisconsin: University of Wisconsin Press, 1980); R. Griffin, The Nature of Fascsim (Oxon: Routledge, 1993).

${ }^{60}$ Albertazzi and McDonnell, op. cit., Ref. 11, p. 3.

${ }^{61}$ Griffin, op. cid., Ref 59, p. 41.

62 See Canovan, op. cid., Ref. 21, pp. 2-16; cf. Abts and Rummens, op. cid., Ref. 11, pp. 405424.

${ }^{63}$ L. March and C. Mudde, 'What's Left of the Radical Left? The European Radical Left After 1989: Decline and Mutation', Comparative European politics, 3(1) (2005), p. 35. 
${ }^{64}$ March and Mudde, ibid., p. 36.

${ }^{65} \mathrm{~S}$. de Lange and M. Rooduijn, 'Een populistische Zeitgeist in Nederland? Een inhoudsanalyse van de verkiezingsprogramma's van populistische en gevestigde politieke partijen', in: R. Andeweg and J. Thomassen (eds.), Democratie Doorgelicht, het functioneren van de Nederlandse democratie (Leiden: Leiden University Press, 2011), pp. 319-334.

${ }^{66}$ P. Lucardie, 'The Netherlands: Populism versus Pillarization', in: D. Albertazzi and D. McDonnell (eds.) Twenty-First Century Populism. The Spectre of Western European Democracy (Basingstoke: Palgrave MacMillan, 2008), p. 154; G. Voerman and P. Lucardie, 'De SociaalDemocratisering van de SP', in: F. Becker and R. Cuperus (eds.), Verloren Slag. De PvdA en de verkiezingen van november 2006 (Amsterdam: Mets and Schilt/Wiardi Beckman Stichting, 2007), pp. 139-164.

${ }^{67}$ See, for example, Rooduijn et al., op. cid., Ref. 30.

${ }^{68}$ See for instance Taggart, op. cid., Ref. 11; Mény and Surel, op. cid., Ref. 2; R. Heinisch, 'Success in opposition - failure in government: explaining the performance of right-wing populist parties in public office', West European Politics, 26(3) (2003), pp. 91-130.

${ }^{69}$ See, for example, Mudde and Rovira Kaltwasser, op. cid., Ref. 8.

${ }^{70}$ D. Albertazzi and D. McDonnell, 'The Lega Nord in the Second Berlusconi Government: In a League of Its Own', West European Politics, 28(5) (2005), p. 953.

${ }^{71}$ A. Zaslove, 'The populist radical right in government: The structure and agency of success and failure', Comparative European Politics, 10(4) (2012), p. 431.

72 Mudde, op. cid., Ref. 24, p. 41.

${ }^{73}$ Deegan-Krause and Haughton, op. cid., Ref. 30.

${ }^{74}$ See C. Mudde, 'In the Name of the Peasantry, the Proletariat, and the People: Populisms in Eastern Europe', in: Y. Mény and Y. Surel (eds.), Democracies and the Populist Challenge (Basingstoke: Palgrave, 2002), pp. 214-232; M. Minkenberg 'The Radical Right in Post-socialist Central and Eastern Europe: Comparative Observations and Interpretations', East European Politics and Society, 16(2) (2002), pp. 335-362. 
75 P. Učeň, 'Parties, Populism, and Anti-Establishment Politics in East Central Europe', SAIS Review, 27(1) (2007), pp. 49-62.

${ }^{76}$ Sikk, op. cid., Ref. 6.

77 See for instance A. Szczerbiak 'Poland's Unexpected Political Earthquake: The September 2001 Parliamentary Election', Journal of Communist Studies and Transition Politics, 18(3) (2002), pp. 41-76.

${ }^{78}$ R. Markowski, 'The Polish Elections of 2005: Pure Chaos or a Restructuring of the Party System?', West European Politics, 29(4), (2006), p. 820.

${ }^{79}$ B. Stanley, Populism in the Polish party system: party appeals and voter mobilization, Doctoral Dissertation, (Colchester: University of Essex, 2010), pp. 233-4.

${ }^{80}$ See F. Millard, Democratic Elections in Poland, 1991-2007, (Oxon: Routledge, 2010), pp. $135-6$.

${ }^{81}$ See A. Szczerbiak, 'Social Poland' Defeats 'Liberal Poland'? The September-October 2005 Polish Parliamentary and Presidential Elections', Journal of Communist Studies and Transition Politics, 23(2), 2007, p. 212.

${ }^{82}$ Sartori, op. cid., Ref. 7, p.p. $1033-1053$.

${ }^{83}$ See Collier and Mahon, op. cid., Ref 9; Goertz, op. cid., Ref. 37.

${ }^{84}$ See P. Mair, 'Concepts and concept formation', in: D. Della Porta and M. Keating (eds.), Approaches and Methodologies in the Social Sciences, (Cambridge: Cambridge University Press, 2008), p. 190.

${ }^{85}$ Mudde, op. cid., Ref. 24, pp. 29-30.

${ }^{86}$ See S. van Kessel, Supply and Demand. Identifying Populist Parties in Europe and Explaining their Electoral Performance, DPhil dissertation, (Brighton: University of Sussex, 2011).

${ }^{87} \mathrm{~T}$. Pauwels, 'The Decline of the National Populist VB and the Rise of the Flemish Nationalist N-VA in Belgium', in: F. Hartleb and K. Grabow (eds.), Right-wing and National Populists in Europe, (Bruxelles: CES-KAS, forthcoming). 
${ }^{88}$ D. McDonnell, 'Silvio Berlusconi's Personal Parties: From Forza Italia to the Popolo Della Libertà', Political Studies, Advance Online Publication (2013), doi: 10.1111/j.1467-9248.2012.01007.x.

${ }^{89}$ See S. van Kessel. 'A Matter of Supply and Demand: The Electoral Performance of Populist Parties in Three European Countries', Government and Opposition, available on CJO2013. doi: $10.1017 /$ gov.2012.14.

${ }^{90}$ Hawkins, op. cid., Ref. 30; Deegan-Krause and T. Haughton, op. cid., Ref. 30; Pauwels, op. cid., Ref. 30, p. 101; Rooduijn et al., op. cid., Ref. 30, p. 3.

${ }^{91}$ Rooduijn et al., op. cid., Ref. 30, p. 2.

${ }^{92}$ See Mair, op. cid., Ref. 84 , pp. 190-1.

${ }^{93}$ Goertz, op. cid., Ref 37, p. 34. 
Figure 1: Ladder of abstraction of populist manifestations

\begin{tabular}{|c|} 
Populist discourse \\
\hline Populist parties \\
\hline Party families with a populist component
\end{tabular}

